\title{
THE HIH COLLAPSE: A COSTLY CATALYST FOR REFORM
}

\author{
GREGOR ALLAN*
}

[This paper examines the corporate governance and audit law reforms wrought in the wake of recent corporate scandals such as the $\mathrm{HIH}$ collapse. It considers the cost of these reforms and, using $\mathrm{HIH}$ as a principle reference point, the likely benefits. In particular, it questions reforms in the areas of auditor independence and audit standards. Do the new independence requirements go far enough? Does audit practice regulation now go too far? Indeed, is the audit function inherently susceptible to legislated sanction - or does this denigrate the very essence of auditing as a profession?]

\section{INTRODUCTION}

The HIH collapse is not 'a case where wholesale fraud or embezzlement abounded'. ${ }^{1}$ Instead, it is a rather pathetic tale in which, to the great cost of thousands of ordinary Australians, the unwary followed the inept further and further toward predictable demise. By the time the group was wound-up on 27 August 2001, its deficiency was estimated at between $\$ 3.6$ billion and \$5.3 billion. ${ }^{2}$ Only two days later, a Royal Commission of Inquiry was established to investigate the cause.

That this saga was allowed to unfold is as much a testament to poor corporate governance as it is to any default on the part of the auditor, Arthur Andersen. Yet recent legislative reforms, although in name targeting both 'corporate

\footnotetext{
* Senior Lecturer and Head of Prosecutions Programme, Centre for Transnational Crime Prevention, Faculty of Law, University of Wollongong. The author gratefully acknowledges the support of Dr Annamaria Kurtovic of the Forensic Accounting Programme, Faculty of Commerce, University of Wollongong.

${ }^{1}$ The HIH Royal Commission Report, 'Reasons for the failure: A broad perspective', National Capital Printing, Canberra, 2003, available at http://pandora.nla.gov.au/pan/23212/20030418/www.hihroyalcom.gov.au/finalreport/i ndex.htm (last accessed December 2004). (Hereinafter referred to as Royal Commission Report. As the report is unpaginated, references herein provide the relevant section title in quotation marks.)

${ }^{2}$ Royal Commission Report, 'The failure of HIH: a critical assessment'.
} 
disclosure' and 'audit reform', have weighed-in very heavily on the audit reform side of the ledger - particularly in the area of auditor independence. This paper discusses the profound changes to the profession that these reforms will herald, including the splitting of audit and non-audit functions, increases in public indemnity insurance, the incorporation of auditing entities (now permitted) and the loss of several small firms hitherto sustained by a balanced diet of auditing and advisory work. To the corporate sector, the cost of doing business just got higher, particularly for listed companies: compliance costs ultimately to be borne by the shareholder - are set to increase dramatically.

Given the cost of reform, the likelihood of ensuing benefits calls for close examination. This paper undertakes such an examination against the backdrop of the $\mathrm{HIH}$ collapse. It is argued that new and convoluted auditorindependence provisions, in conjunction with the move to brace auditing standards with the force of law, verge on 'black-letter' proscriptions that obscure the very hallmark of professional practice - the ascription to an overarching body of ethics. It is further argued that the standard of independence now legislated tolerates market uncertainty and, accordingly, falls well shy of the mark. Indeed, it is suggested that the entire thrust of the reforms miss the most obvious target. An invariable modus operandi of the corporate malfeasor is the deceptive, technical manipulation of accounting and auditing standards, yet there is a growing body of accounting professionals with little or no understanding of the application of the 'true and fair view' requirement of financial reporting. If the auditing profession wishes to avoid the slide to technocracy, it is argued that the 'true and fair view' requirement must be uncompromisingly reasserted as the ultimate financial reporting standard - not lost amid the clamorous, technical detail of recent reforms.

\section{HIH: INEPTITUDE MASKED BY DECEIT}

\section{A Ineptitude and the 'shambling journey towards oblivion, ${ }^{3}$}

It is said that bad management and poor accounting cause most corporate failures. ${ }^{4}$ The most striking testament to bad management at HIH was, without

\footnotetext{
${ }^{3}$ This is the description applied to the HIH collapse by the Royal Commission: Royal Commission Report, 'The failure of HIH: a critical assessment'.

${ }^{4}$ 'Over 50 percent of companies fail because of these two things': John Spark, partner at Ferrier Hodgson. To similar effect are the comments of George Lopez, partner with insolvency specialist Melson Robson and chairperson of CPA Australia's Insolvency
} 
doubt, its chronic under-reserving. As the Royal Commission Report noted, 'the largest single item on the balance sheet of the general insurer is the provision that sets aside for payment of future claims'. ${ }^{5}$ In making this provision, the HIH board relied upon reports of independent actuaries and assessments of those reports by its auditor, Arthur Andersen (Andersen). However, 'at no time were the actuary reports or even a summary of them tabled at meetings of the audit committee or board ... nor was an actuary asked to attend the meeting to explain his or her report or answer questions'. 6 Indeed, the inefficacy of the $\mathrm{HIH}$ board is a theme that permeates the entire Royal Commission report. The Commission noted that 'there were no clearly defined limits on the authority of the chief executive' and that, as a result, in some areas 'the system was out of control and the board did not appreciate it'. ${ }^{7}$ The board did not have 'a well understood policy on matters that would be reserved to itself ... matters seem to have come forward at the discretion of the chief executive'. ${ }^{8}$ The agenda for the board was 'controlled by management'. ${ }^{\text {' }}$

This abdication of directorial responsibility was itself a function of a doting, but thoroughly blind, faith in the HIH management. Whilst a degree of deference to the experience of senior management must undoubtedly attend a board's deliberations, the Royal Commission noted that in the modern commercial context [this] must be subject to the countervailing effect of close review, debate and questioning ... this appears to have been a commodity in short supply at $\mathrm{HIH}^{\prime}{ }^{10}$ The Commission appositely referred to a 1995 due diligence report which described $\mathrm{HIH}$ as a company 'struggling to make the transition from an entrepreneurially run company influenced strongly by senior management' to an 'ASX listed company run in the interests of shareholders'. ${ }^{11}$ Worse still, the influence of senior management was effectively institutionalised through the composition of both the board and the audit committee. Amongst the S\&P/ASX top 100 companies, independent

and Reconstruction Centre of Excellence: 'the issue that comes up quite consistently is the lack of information. The failure to keep proper records. It is not just necessarily not having enough information but not having the right information': , Both quoted in Ed Charles and Trevor Murphy, 'Bad company’ (2002) 72(7) Australian CPA 6.

${ }^{5}$ Royal Commission Report, 'The audit methodology'.

${ }^{6}$ Royal Commission Report, 'Under-provisioning: systemic problems'.

${ }^{7}$ Royal Commission Report, 'Limits of authority'.

${ }^{8}$ Ibid.

${ }^{9}$ Ibid.

${ }^{10}$ Royal Commission Report, 'Mismanagement: a particular outlook'.

${ }^{11}$ Royal Commission Report, 'A private company approach'. 
non-executive directors comprise on average 45.3 percent of the board; in stark contrast, there were no independent non-executive directors on the $\mathrm{HIH}$ board. ${ }^{12}$ Of the four non-executive directors, two were former partners of Andersen and two were involved in providing legal services to the group. ${ }^{13}$ Nor did HIH have a single independent director on the audit committee; by contrast, in 54 percent of the top 100 companies the audit committee is exclusively comprised of independent, non-executive directors. ${ }^{14}$

Moving still deeper into the heart of the problem, it is apparent that $\mathrm{HIH}$ altogether lacked an identifiable long-term strategy and, accordingly, developed only opportunistically. The company's decision to re-enter the US market typifies this, premised as it was upon purely anecdotal evidence and following a well-reasoned strategic decision to withdraw from the market only a few years earlier. The decision to purchase FAI without due diligence, ${ }^{15}$ the expansion into the UK market and the Allianz joint venture - a woeful decision with patently predictable yet thoroughly crippling effects on HIH's vital, insurance-premium income stream ${ }^{16}$ - offer further examples.

\footnotetext{
${ }^{12}$ Report prepared for HIH Royal Commission by Institutional Analysis Pty Ltd, cited in Philomena Leung and Barry Cooper, 'The Mad Hatter's Corporate Tea Party' (2002) 18(6) Managerial Auditing Journal Iss 6/7 505.

${ }^{13}$ Ibid.

${ }^{14}$ Ibid. Independence problems also plagued the audit committee of Harris Scarfe: the committee comprised only three members, two of whom were clearly internal including the chief financial officer, Alan Hodgson. Such lack of independence completely undermines the audit committee function of ensuring efficient and effective communication between senior management and the external auditors.

${ }^{15}$ Although very much alive to the difficulties of 'persuading a takeover target to open its books to a suitor who is also a competitor', the Commission noted that the takeover decision was reached after only a perfunctory meeting and was catalysed by fears that a third party's bid was imminent: Royal Commission Report, 'Mismanagement: A failure of culture'.

${ }^{16}$ The joint-venture agreement required not only that HIH contribute approximately $\$ 500$ million to a joint venture trust but that its premium income be paid into that trust, to become available for distribution only on a quarterly basis and following actuarial assessment. With sardonic understatement, the Commission noted that it was 'somewhat bewildering' that no one at management or board level even called for an accurate analysis of the likely cash flow implications of the transaction: Royal Commission Report, 'The harbinger of doom: The Allianz joint-venture'.
} 


\section{B Deceit}

Whilst it is certainly possible to identify specific, catalytic transactions, these individual decisions merely implicate more fundamental, underlying deficiencies in the 'corporate culture' and structure of the HIH group itself. The Commission noted that 'the board - the ultimate decision maker - could rely on management and the auditors only if it was satisfied that the accounts had been derived from systems that would likely produce accurate returns after diligent search and inquiry into relevant and material matters'. ${ }^{17}$ However, the information systems at HIH 'left much to be desired', with the result that management itself was 'often flying blind'. ${ }^{18}$ Worse, 'there was a filtering of information such that, on occasions, bad news reached the board only if it could not be avoided' ${ }^{19}$ As is so often the case, this deception was effected with the complicity of unscrupulous accounting: 'put bluntly, $\mathrm{HIH}$ management recognised that the group was under-performing at a level that could not be sustained ... it used and relied on questionable transactions giving rise to doubtful accounting entries, which disguised the seriousness of the situation ... the process was fatally flawed'. ${ }^{20}$ Such entries included extensive one-off entries by way of increments to goodwill and recoveries under reinsurance contracts. ${ }^{21}$ In the Commission's view, accounting practices became 'a repository of the unpleasant'.

In such an environment, one might reasonably ask: where were the auditors?

\section{THE AUDITORS}

\section{A Lack of professional scepticism}

Unquestionably, the HIH story is also one of auditor failure. Although the extent to which Andersen's failures were ultimately causative of the group's collapse is necessarily speculative, it is informative to note that between 1998 and 2001 the firm had employed a client-risk assessment mechanism (dubbed 'SMART') that had consistently assessed $\mathrm{HIH}$ as a maximum-risk client. ${ }^{22}$ Its

\footnotetext{
${ }^{17}$ Royal Commission Report, 'The accounting function'.

${ }^{18}$ Royal Commission Report, 'The integrity of information sources'.

${ }^{19}$ Ibid.

${ }^{20}$ Royal Commission Report, 'Aggressive accounting practices'.

${ }^{21}$ The desire to mask problems could be seen also at board level, the fateful Allianz joint-venture being announced as a 'value enhancing strategy' only the day before the presentation of HIH's very poor end-of-year results: ibid.

${ }^{22}$ Royal Commission Report, '21.3 Audit approach'.
} 
internal operations manual accordingly required the firm to employ expanded risk management procedures and to formulate a formal risk management plan in this respect. ${ }^{23}$ Given the extremely high materiality of any potential misstatement in relation to the provision for future claims, Andersen's own policies required that the reports of the consulting actuary be subject to rigorous review. Remarkably, however, the firm 'generally relied on extracts from six monthly reports that Slee [the principal consulting actuary] prepared ... which were received before the finalisation of the year-end accounts' and which 'generally speaking ... provided scant detail as to Slee's methodology and assumptions' ${ }^{24}$ Moreover, the firm did not engage any expert assistance in considering these extracts. ${ }^{25}$

Whilst Andersen's unquestioning acceptance of the actuary's reports was arguably the firm's principal failure, it formed merely an aspect of an overall lack of inquisitive rigour. In particular, Andersen relied extensively upon HIH's internal business audit processes. Indeed, the firm relied on those processes without conducting any evaluation or testing of the operations, policies and procedures of internal audit function, ${ }^{26}$ - even though the audit team had identified deficiencies in the internal audit division and even though Andersen's own operations manual mandated such evaluation and testing. ${ }^{27}$

\section{B 'Aggressive accounting practices' ${ }^{28}$}

The firm also failed to deal with a number of accounting anomalies. These were identified by the Royal Commission as falling into four main categories, namely: accounting for future income-tax benefits, deferred acquisition costs, deferred information technology costs and goodwill.

In the case of future income-tax benefits, the relevant accounting standard makes plain that, where a company incurs a tax loss, significant doubts must arise about the company's ability to realise the related future income-tax

\footnotetext{
${ }^{23}$ Quite apart from Andersen’s internal manual, this is a requirement of AUS 206.

${ }^{24}$ Ibid.

${ }^{25}$ Ibid.

${ }^{26}$ Indeed, Andersen did not even perform a review of the audit division's working papers: Royal Commission Report, '21.3.1 Audit methodology: Reliance on the work of others'.

${ }^{27}$ Again, this was also a requirement auditing standards (AUS 604).

${ }^{28}$ This is how the Royal Commission euphemistically branded HIH's accounting methodology: Royal Commission Report, 'Aggressive accounting practices'.
} 
benefits in subsequent periods. ${ }^{29}$ Although a 'virtual certainty' test is posited, Andersen's engagement partner testified that he applied the far less exacting test of whether there were 'reasonable grounds to believe that HIH would continue to operate profitably in the future'. In the Commission's view, the auditor failed to obtain sufficient appropriate evidence under AUS 502 and should have issued a qualified opinion.

A similar story can be told in relation to the accounting for deferred acquisition costs. Before acquisition costs incurred in obtaining and recording policies of insurance can be deferred and recognised as assets, they must be capable of reliable measurement and must more likely than not give rise to premium revenue in subsequent financial years. ${ }^{30}$ In this case, Andersen did no work with respect to the recoverability of deferred acquisition costs, relying instead, 'as a matter of professional judgement', upon HIH's historical profitability. ${ }^{31}$ Again, insufficient evidence was obtained under AUS 502.

Although at the time there were no specific accounting standards relevant to deferred information technology costs, Statement of Accounting Concepts 4 (SAC 4) posited a test comparable to that for deferred acquisition costs namely, that the future economic benefits be both probable and reliably measurable. Again, the Commission questioned whether Andersen obtained sufficient appropriate evidence in this respect.

Significant questions were also raised with respect to Andersen's accounting for goodwill. Again, the test is whether future benefits will eventuate and whether goodwill can be measured reliably. ${ }^{32}$ As at June 2000, goodwill represented a staggering 50 percent of HIH's shareholder funds. This compares with 4.9 percent for QBE Insurance and 0.4 percent for NRMA. ${ }^{33}$

The extent to which the diabolical Allianz transaction can be attributed to auditor failure is not without controversy. Andersen was supplied only basic details of the transaction. Moreover, it is not the role of the auditor to presage the commercial prudence of a client's business decisions. However, any financial report must entail an assessment of an entity's ability to continue to operate as a going concern; the truth and fairness of this assessment was one falling squarely within the audit function. In this respect, the Commission

\footnotetext{
${ }^{29}$ AASB 1020

30 AASB 1023.

${ }^{31}$ Royal Commission Report, '21.5.5 Deferred acquisition costs'.

${ }^{32}$ AASB 1013

${ }^{33}$ Royal Commission Report, 'Reliance on intangibles'.
} 
again found that Andersen displayed a lack of professional scepticism: 'Andersen exhibited a willingness to embrace the Allianz transaction as a panacea in respect of a number of critical and fundamental audit issues in the 2000 audit without obtaining sufficient analytical evidence about the transaction and its potential financial consequences'. ${ }^{34}$

\section{Independence?}

The independence of Andersen was also highly questionable. Three former partners of the firm sat on the HIH board. One, who was the recipient of continuing benefits from Andersen, was made chairman and was appointed to the audit committee only 17 months after his retirement. Another, who had been the engagement partner, was made chief financial officer only the day after his resignation from the firm. The third was appointed to the board only five months after his retirement, having 'played a significant role in the audit of HIH for 25 years'. ${ }^{35}$ Moreover, in 1999 Andersen's longstanding HIH-audit engagement partner was replaced after he met with non-executive directors in the absence of senior management.

Highlighting Andersen's close personal relationships to $\mathrm{HIH}$ and its unquestioning acceptance of the results of both the company's internal audit processes and the work of its consulting actuary, counsel assisting the Commission mounted an extremely cogent argument to the effect that Andersen was not, in fact, independent in its conduct of the 1999 and 2000 audits. The point was also made that Andersen's partners were under considerable pressure to maximise profits through the provision of non-audit services. ${ }^{36}$ Indeed, one of the Andersen partners stated in evidence before the Commission that, if he was called upon to exercise independent and professional scepticism by resisting management proposals, it would have adversely affected his ability to promote the supply of non-audit services to HIH.37 Notwithstanding the considerable probity of the counsel's

\footnotetext{
${ }^{34}$ Royal Commission Report, '21.6.3 Conclusion' (this section constituting the conclusion to a chapter entitled 'The Audit Function'). The Commission had 'serious doubts' whether the group accounts for 1999 and 2000 could probably have been prepared on a going concern basis: ibid.

${ }^{35}$ Royal Commission Report, '7.2.3 Audit independence - employment situations'.

${ }^{36}$ One of the 'cornerstones' in the evaluation of the performance of Andersen partners and staff was the success and facilitating the use of non audit services: Royal Commission Report, '21.4.5 Fee maximisation'.

${ }^{37}$ Ibid.
} 
submissions, the Commission found a lack of independence only in appearance, not in fact. ${ }^{38}$

\section{REFORM}

Although certainly the largest collapse, the demise of HIH was only one of a number of high profile and dramatic failures. Others included Harris Scarfe and One.Tel. Harris Scarfe's chief financial officer, Alan Hodgson, is currently serving a sentence of six years for having played a leading role in the falsification of company accounts and reports, thereby allowing the company to trade when it was virtually insolvent. Indeed, in testimony before the Supreme Court of South Australia, Hodgson stated that he had effectively authorised accounts to be changed on cue to comply with profit results stipulated by either the company's managing director or its chairman. ${ }^{39}$ Similarly, One.Tel's strategic decision to invest in its own telecommunications system wrought such financial strain that ultimately its accounts were manipulated in order to hide losses (principally through the conversion of expenses into capital expenditure) and to ensure that 'unreal salaries and bonuses would continue to be paid' ${ }^{40}$ Unsurprisingly, recent reforms have sought to bolster principles of corporate governance, improve the quality of financial reporting and improve audit quality, particularly through measures aimed at safeguarding auditor independence. These reforms were effected via the passage of the Corporate Law Economic Reform Programme (Audit Reform and Corporate Disclosure) Act ('the CLERP 9 Act') on 25 June 2004.

\section{A Tweaking corporate governance}

On the corporate governance side, the reforms require, inter alia, chief executive officers and chief financial officers of listed companies to declare in the annual report that the financial records have been properly maintained, comply with accounting standards and 'give a true and fair view' ${ }^{41}$ Listed

\footnotetext{
${ }^{38}$ In reaching this conclusion and after traversing in considerable detail the various possible tests for the requisite standard of 'perceived independence', the Commission applied by analogy the test of judicial independence: to an informed observer, 'could' the circumstances surrounding the audit engagement give rise to a perception of partiality: Royal Commission Report, 'Other models for dealing with conflict'.

${ }_{39}$ Philomena Leung and Barry Cooper, 'The Mad Hatter's Corporate Tea Party' (2002) 18(6) Managerial Auditing Journal Iss. 6/7 505.

${ }^{40}$ Ibid.

${ }^{41}$ Corporations Act 2001 (Cth) s 259A.
} 
companies must also include details of directors' remuneration, as well as performance targets for directors. ${ }^{42}$ Shareholders must be given time to discuss those targets at annual stockholders meetings. ${ }^{43}$ Institutional investors will therefore be able to decide whether financial targets are sufficiently high and whether or not they were reached before executive bonuses were paid. ${ }^{44}$ Management discussion and analysis too is now mandatory in the financial reports of listed companies: shareholders are to receive such information as they 'would reasonably require' to make an informed assessment of 'the operations of the entity', its financial position and its 'business strategies and prospects for future financial years' ${ }^{45}$ Following recommendations of the HIH Royal Commission which highlighted inadequacies in identifying company office-holders, individual liability under the Corporations Act is now determined on the basis of function rather than title or position. ${ }^{46} \mathrm{~A}$ Financial Reporting Panel, vested with the power to summon witnesses and to take evidence, ${ }^{47}$ has also been established to rule on disputes arising between a company and the corporate regulator, ASIC. ${ }^{48}$ The passage of CLERP 9 also introduced whistleblower protection designed to encourage employees to report suspected breaches of the Corporations Act. ${ }^{49}$ Perhaps the most dramatic reforms, however, have been in the area of auditor independence.

\footnotetext{
${ }^{42}$ Corporations Act 2001 (Cth) s 300A(1)(b).

${ }^{43}$ Corporations Act 2001 (Cth) s 250SA. Shareholders' views are not, however, binding upon directors: s 250R.

${ }_{44}$ Alan Kohler, 'New Rules will Show which Master Chiefs Serve', The West Australian, 7 August 2004, 65.

${ }^{45}$ S229A.

${ }^{46}$ See, eg, s 295A (containing a definition of the 'chief executive function' and 'chief financial officer function' for the purpose of determining liability for the additional declarations now required in the financial reports of listed entities).

${ }^{47}$ Corporations Act 2001 (Cth) s 239CE.

${ }^{48}$ Corporations Act 2001 (Cth) s 239AA. The notion of such a panel was proposed by ASIC due to fears that the courts would adopt inappropriate, legalistic interpretations of accounting standards. The regulator pursued the concept after it received an adverse judgement on a matter involving software developer MYOB: 'Coming to terms with CLERP 9', (July 2004) The Accountant 2. The establishment of the Financial Reporting Panel has been generally applauded, although some have argued that its jurisdiction is too limited: the panel is restricted to ruling only on disputes that arise after a company has published its accounts and where ASIC asserts that there has been non-compliance with accounting standards: 'CLERP 9 disputes panel reforms attacked as being inadequate', The Accountant, October 2003, 1.

${ }^{49}$ Corporations Act 2001 (Cth) s 1317AE (contained in an entirely new part of the Corporations Act 2001: Part 9.4AAA - Protection for Whistleblowers).
} 


\section{B The independence requirements}

Prior to recent reforms, the Corporations Act dealt with the issue of auditor independence by focusing on specific indicia of objectivity, such as indebtedness and employment relationships between the company and its auditor. Now, however, the Act enshrines 'Professional Statement F1', an independence standard developed and adopted by the profession itself..$^{50}$ The standard requires auditors to identify specific threats to independence and to apply safeguards reducing them to an acceptable level: it is now an offence under the Corporations Act for auditors aware of a conflict of interest situation to fail to 'take all reasonable steps to ensure that [the situation] ceases to exist' ${ }^{51}$ Auditors unaware of a conflict situation will still be caught if they failed to operate 'a quality control system reasonably capable of making the individual auditor or audit company aware of the existence of [the situation], ${ }^{52}$ Similar liability attaches to directors of audited companies. Indeed, it is an offence for even an employee of an audit firm, whether associated with the engagement or not, to fail to notify ASIC within seven days of a known conflict. ${ }^{53}$ Auditors must now also provide written declarations that there have been no contraventions of the auditor independence requirements of the Corporations Act or of 'any applicable code of professional conduct ${ }^{54-}$ failure to do so constitutes a strict liability offence. ${ }^{55}$ The independence requirements are extremely convoluted, even including 'maximum hours tests' (that vary depending upon the level of audit involvement) for the provision of non-audit services. Directors' statements on annual reports must detail any non-audit services provided by an external auditor, including fees paid for such services, and provide an explanation as to why the audit committee is satisfied that the provision of the services does not compromise independence. As Senator Ian Campbell said in releasing the draft bill for discussion, 'we're going to give the standard the force of law by saying to companies that if you depart from F1, you will have to explain in your annual report why'. ${ }^{56}$

${ }^{50} \mathrm{~F} 1$ was developed by the International Federation of Accountants and is applied in Australia under the ICAA and CPAA's Joint Code of Professional Conduct.

${ }^{51}$ Corporations Act 2001 (Cth) s 324CA(1).

${ }^{52}$ Corporations Act 2001 (Cth) s 324CA(2).

${ }^{53}$ Corporations Act 2001 (Cth) s 324CA(1A).

${ }^{54}$ Corporations Act 2001 (Cth) s 307C(1)(c).

${ }^{55}$ Corporations Act 2001 (Cth) s 307C(3).

56 Mark Abernethy, 'Campbell's law', (November 2002) 73(10) CA Charter 34. Although significant, this measure falls short of United States' reforms which, by virtue of the Sarbanes-Oxley Act, impose a blanket prohibition on the provision of non-audit services by an external auditor. In the view of HIH Royal Commission, there was a 'respectable argument' in favour of a blanket prohibition also in Australia, 
Further independence requirements impose restrictions on the composition of the audit team. The audit partner, and other personnel who 'play a significant role' (the meaning of which is defined, along with other nebulous terms such as 'audit critical employee ${ }^{57}$ ) in the audit of listed companies must be rotated every five years. ${ }^{58}$ Once rolled off, such personnel cannot return to an engagement for at least two years. ${ }^{59}$ Further restrictions bolster these requirements. No more than one former ex-partner of an external auditor can be appointed to the directorship or senior management of a former audit client. ${ }^{60}$ Moreover, audit and review partners are unable to accept such appointments for a period of two years following resignation. ${ }^{61}$

\section{The watchdogs and standard-setters}

The CLERP 9 Act has also wrought significant institutional changes, particularly within the Financial Reporting Council. The FRC has traditionally been responsible for overseeing the accounting standards-setting processes of the private and public sectors; its role has been advisory, being the key policy adviser to government on accounting standards and determining the broader, strategic direction of the standard-setter itself, the Australian Accounting Standards Board. This role has now been considerably expanded in deference to recommendations by Professor Ian Ramsay in his report to the Federal Government on corporate-governance reforms (the acclaimed 'Ramsay report'). Professor Ramsay urged the establishment of an auditing and accounting public oversight board. Ultimately, however, government came to the view that 'the FRC was virtually the same as what Professor Ramsay was

particularly due to the 'pressure upon the audit personnel to procure non-audit work by maintaining a strong relationship with management': Royal Commission Report, '7.2.2 Audit independence - non-audit work'. Ultimately, however, the Commission supported the draft bill on the strength of a further recommendation to the effect that the marketing of non-audit services ought 'form no part of the performance evaluation criteria for audit partners and personnel': ibid.

${ }^{57}$ Corporations Act 2001(Cth) s 9.

${ }^{58}$ Corporations Act 2001(Cth) s 324DA(1).

${ }^{59}$ Corporations Act 2001(Cth) s 324DA(1)(a).

${ }^{60}$ Corporations Act 2001(Cth) s 324CK.

${ }^{61}$ Corporations Act 2001(Cth) s 324CI. These reforms all follow recommendations for additional protections made by the HIH Royal Commission. Professional standard F1 and the Ramsay Report had both subscribed to a seven-year rotation period for partners only. However, the Commission also recommended 'cooling off' periods of four years following resignation for 'senior audit personnel' and two years only for a 'former partner not directly involved in the audit': Royal Commission Report, 'Recommendations'. 
suggesting' and that, with a revised mandate and in a reconstituted form, the Council could be 'established as the pre-eminent public oversight board for audit and accounting, ${ }^{62}$ Consequently, the audit standard-setter, the Auditing \& Assurance Standards Board (AuASB) ${ }^{63}$, now also falls within the purview of the FRC. ${ }^{64}$ This is of especial significance because, as a result of further reform, auditing standards set by the AuASB now have legislative backing: under s307A, it is a strict liability offence to conduct an audit other than in accordance with the Board's auditing standards. ${ }^{65}$ Moreover, the advisory function of the FRC is supplemented by a compliance role. In conjunction with the professional bodies, the FRC is to monitor both auditor independence and audit quality. ${ }^{66}$ In furtherance of this function, the FRC will have the power to gather information from professional accounting bodies and accounting firms, including audit working papers ${ }^{67}$ (which must be retained for at least seven years ${ }^{68)}$. These powers will override any claims to client confidentiality. ${ }^{69}$

The primary corporate regulator, the Australian Securities and Investments Commission (ASIC), is also to monitor compliance with auditing standards and independence requirements. To this end, the Commission has received a funding increase of some $\$ 74$ million over the past two budgets ${ }^{70}$ and has announced a comprehensive two-year Audit Surveillance Project. ${ }^{71}$ Under this project, ASIC will select companies both randomly and using risk-based methodologies. Non-compliance with relevant accounting standards

\footnotetext{
${ }^{62}$ Senator Ian Campbell, quoted in 'Campbell's law', above n 56.

63 The AuASB is itself newly constituted under s227B.

64 'In performing its functions, the AUASB must... follow the broader strategic direction determined by the FRC': Corporations Act 2001(Cth) s234C(a). The AuASB is also to have a government-appointed chairperson: Corporations Act 2001(Cth) 236F.

${ }^{65}$ Corporations Act 2001(Cth) s 307A.

66 'The FRC functions include... monitoring and assessing the nature and overall adequacy of... the systems and processes used by Australian auditors to ensure compliance with audit independence requirements': Corporations Act 2001(Cth) s225(2B). This is an extension of the powers envisaged for the FRC in the CLERP 9 discussion paper.

${ }^{67}$ Corporations Act 2001(Cth) s 225A

${ }^{68}$ Corporations Act 2001(Cth) s 307B

69 Ibid.

70 'ASIC warns it will audit the auditors', The Australian Financial Review, (Sydney), 7 July 2004, 1.

71 'What's New? ASIC's Surveillance Project 2003-2004', (October 2003) 79(9) CA Charter, 64.
} 
constitutes one of the applicable risk criteria. ${ }^{72}$ The first year commenced in October 2004 and focused upon F1 independence: it entailed on-site inspections of 440 auditing and small accounting firms to ensure implementation of 'systems to ensure independence'. ${ }^{73}$ In the second year, ASIC will 'expand the programme to cover audit firms with a smaller numbers of listed company clients' and 'over time, will cover all audit firms on a systematic basis'. ${ }^{74}$ The Commission proposes examining individual engagements 'only if there is a problem identified through our other surveillance activities'. ${ }^{75}$

ASIC's responsibility for audit quality assurance extends also to mandating the educational requirements for official registration as a company auditor. ${ }^{76}$ Registrants must either complete specialist courses that are stipulated by way of regulation or meet ASIC-approved competency standards. ${ }^{77}$

Further still, in a somewhat radical step that has not been implemented anywhere else in the world (including the United States) the Commission now has the power to issue infringement notices for alleged market-disclosure breaches. $^{78}$ The power was one sought by ASIC itself: 'from time to time, some companies are not giving as much emphasis to their obligations to the market as we think is required ... we argued for a remedy that was proportionate and able to be used quickly, as an alternative to very expensive litigation'. ${ }^{79}$

The expanded role of the FRC has naturally required some settling of turf with ASIC. Pursuant to a Memorandum of Understanding signed in June

\footnotetext{
${ }^{72}$ Ibid.

${ }^{73}$ ASIC Chief Accountant, Mr Greg Pound, quoted in 'Regulator Starts Auditor Watch', The Australian Financial Review, (Sydney), 1 October 2004, 3.

${ }^{74}$ ASIC Chief Accountant, Mr Greg Pound, quoted in 'Audit Surveillance Round Announced', Western Australian Business News, (Perth) 14 October 2004 available electronically via Dow Jones Reuters Business Interactive LCC (trading as Factiva) (last accessed 13 November 2006).

${ }^{75}$ ASIC Chief Accountant, Mr Greg Pound, quoted in 'Regulator Starts Auditor Watch', above n 73.

${ }^{76}$ Corporations Act 2001(Cth) s 1280A. For a good review of ASIC's responsibilities in this respect, see 'CPA's Reap CLERP 9 Benefits' (2004) 74(6) Australian CPA 6.

${ }^{77}$ Ibid. ASIC may also impose conditions on registration: s1289A.

${ }^{78}$ Corporations Act 2001(Cth) s 1317DAC.

${ }^{79}$ ASIC Executive Director, Policy \& Markets, Mr Malcolm Rodgers, quoted in 'ASIC Warns it will Audit the Auditors', The Australian Financial Review, (Sydney), 7 July 2004, 1.
} 
2004, ASIC will continue to be principally responsible for 'surveillance, investigation and enforcement of the responsibilities of companies in relation to financial reporting', including 'the enforcement of auditor independence requirements' of the Corporations Act. ${ }^{80}$ ASIC will provide the FRC with details of its quality assurance review processes and will keep the Council abreast of disciplinary proceedings. For its part, the FRC will focus more on 'monitoring and assessing the nature and overall adequacy of the auditor independence arrangements', with its evidence-gathering powers being used to 'order related disclosure'.

\section{TOKENISM OR EFFECTIVE COUNTERMEASURES?}

\section{A More than tokenism}

The above reforms are clearly not mere criticism-deflecting adjustments pitched by the accounting profession in a desperate bid to cling to selfregulation. Indeed, principally through the Institute of Chartered Accountants of Australia, the profession opposed many of them. ${ }^{82}$ The 'vast majority of submissions, apart from ASIC', ${ }^{83}$ were strongly opposed to giving auditing standards the force of law: 'auditing standards are already enforceable by ASIC through the Company Auditors \& Liquidators Disciplinary Board' ${ }^{84}$ In a similar vein, the ICAA was 'disappointed' that the CLERP 9 bill failed to augur a greater role for the Financial Reporting Panel in resolving genuine standard-compliance issues prior to the publication of accounts. ${ }^{85}$ The Institute also had reservations as to the potential scope of a reconstituted FRC: 'it should be made clear that it is only oversight, with the detailed monitoring of auditors continuing to be subject to the independent quality review

80 'ASIC, FRC Cooperate on CLERP 9', The Australian Financial Review, (Sydney), 2 July 2004, 2.

81 Ibid.

${ }^{82}$ Nor were the reforms unanimously acclaimed by the corporate sector. ASIC's power to issue infringement notices was especially controversial. The Australian Institute of Company Directors criticised the move as 'an example of introducing new legislation where adequate regulation exists', referring to ASIC's power to seek injunctions without undertakings as to damages: 'the courts have been quick and flexible in granting these injunctions... ASIC should make more use of its enforceable undertakings power': 'No more legislation needed', (March 2003) 74(2) CA Charter 17.

83 'CLERP 9 bill on the table' (2003) 74(10) CA Charter 21.

84 Ibid.

85 'CLERP 9 disputes panel reforms attacked as being an adequate', (October 2003) The Accountant 1 (quoting ICAA Chief Executive, Stephen Harrison). 
programs of the accounting bodies' ${ }^{86}$ On the crucial issue of auditor independence, the Institute took the position that 'the independence of the auditor is vital, but independence is not the objective itself' ${ }^{87}$ In building on this argument, the ICAA voiced concern at, inter alia, the legislature's preference for micro-managing, technical detail rather than 'appropriate independence standards' and at the 'intrusive cooling-off period for professional staff not intimately engaged in audits, ${ }^{88}$

\section{B Effectiveness: A question of costs and benefits}

Although the CLERP 9 Act firms-up on corporate disclosure requirements, it is the illegalisation of non-compliance with auditing standards and independence requirements that are its dominant features. The independence requirements entail some of the most convoluted and ornate legislative drafting to have graced Australia's statute books. The prospect of actually pursuing charges for non-compliance would make a prosecutor shudder. Yet, notwithstanding the profession's protestations otherwise, criminalisation will doubtless have a strong deterrent effect: professional persons might reasonably be assumed to be peculiarly sensitive to the stigma and reputational fallout attendant upon any conviction.

Weighing-in against deterrent theory, however, are those who point out the costs of complying with the new regime. Because of likely costs, the Financial Sector Advisory Council had long argued against an 'overreaction to scandals such as the HIH collapse' ${ }^{89}$ As it happens, however, the Australian Financial Review now estimates that the top 50 listed companies face a combined annual compliance cost of $\$ 375$ million. ${ }^{90}$ The Australian Bankers Association has estimated that the compliance costs for big banks would likely increase by $\$ 125$ million - an increase of 20 percent. ${ }^{91}$ In a survey of 69 large international employers operating in Australia, over 40 percent acknowledged that they had not adequately budgeted for the additional costs,

\footnotetext{
86 'CLERP 9 - Where We Stand' (2003)74(1) CA Charter, 40.

87 'CLERP 9 bill on the table', above $n 83$.

${ }^{88}$ Ibid.

89 'Regulation can go too far: report', The Australian Financial Review, (Sydney), 3 August 2004, 3.

90 'Beware overkill on regulation', The Australian Financial Review (Sydney), 5 July 2004 62. This figure also includes the cost of complying with the Australian stock exchange's corporate governance guidelines.

91 'Backlash against regulation costs', The Australian Financial Review, (Sydney), 5 July 2004, 1.
} 
most pointing to additional measures rendered necessary by the requirement that the chief executive officer and chief financial officer sign-off on their internal control systems. ${ }^{92}$

The extreme emphasis placed upon auditor independence is odd given that lack of auditor independence, although identified, was not specifically implicated as causative of the disasters that sparked these reforms. As discussed above, in the case of HIH there was no actual lack of independence, merely the existence of circumstances which, applying the stringent test adopted by the Commission, could have given rise to a perception of partiality. ${ }^{93}$ This raises another point: even assuming a need for radical reform in the area of auditor independence, it is most peculiar that the CLERP Act fails to impose the stringent independence test so cogently advocated by the Commission. Under s324CD, a 'conflict of interest situation' exists either where 'objective and impartial judgement in relation to the conduct of the audit' is not possible or where a reasonable person 'would conclude' that such judgement is not possible (emphasis added). The difference between the two formulations is far from semantic: the Commission's test precludes the mere possibility of perceived impartiality whereas the second limb of the test in $\mathrm{s}$ 324CD tolerates it. Moreover, as was specifically noted by the Commission, finding evidence of actual bias is extremely problematic; invariably, resort must be made to the second limb: perceived bias. Any relaxation of the standard imposed by this second limb strikes at the very core of the independence requirement. As is attested by the move towards international standardisation of accounting and auditing standards, confidence in financial reporting is essential to market efficiency. It is difficult to fathom why the Australian Government, as part of a wholesale revamp of auditor independence, should ultimately set a standard that permits marketplace uncertainty.

The issue of appropriate standard aside, the auditor independence requirements are likely to manifest more profoundly than simply through increased compliance costs. To minimise risk, many of the larger accounting firms have already hived-off their consulting arms and are refocusing on the more traditional activities of auditing, accounting and provision of tax

\footnotetext{
92 'Reality of compliance hits Australian businesses', The Accountant, 30 September 2004.

${ }^{93}$ However, as was urged by counsel assisting the Royal Commission, the evidence tending to establish actual bias was extremely strong. It is a little surprising that no finding of actual bias was made.
} 
advice. ${ }^{94}$ For smaller practices, 'it may well be that, because of those same risks and the heavy professional indemnity insurance burden, some who trained as accountants will move away from the statutory areas and into business consulting, ${ }^{95}$ For this reason, CPA Australia was vocal in its criticism of the CLERP 9 bill, noting that listed companies vary greatly in size and that the legislation's 'one-size-fits-all' approach is 'significantly different to the corporate law frameworks of other countries, where size tests are used to differentiate requirements' ${ }^{96}$ Further, the ICAA interestingly inferred that the five-year maximum for audit engagement and review rotation might ultimately institutionalise an independence threat:

When regard is had to the smaller audit firms and those audits that are conducted in other than Sydney and Melbourne, there is a real concern that a five-year period will be difficult to comply with and will result in both a move to the larger audit firms and a concentration of listed company audits in Sydney and Melbourne. ${ }^{97}$

The business community has voiced its own misgivings about being forced to 'buy what is perceived as independent advice, but may not be the best possible advice': ${ }^{8}$

Independence is now something at the forefront of everybody's mind. One classic example is the move to international accounting standards. Who do you go to? Do we go with our auditor[?]... Who else can you get advice from? Let us go to another one of the Big Four competitors which doesn't know much about us and which has been trying to get into us, whereas the external auditor would have more knowledge and be able to help better, that would be a classic independence-impairing situation. ${ }^{99}$

\footnotetext{
94 'Brave New World' (2003) 74(1) CA Charter 37.

${ }^{95}$ Ibid.

96 'Unfinished business', (December 2003) 73(11) Australian CPA 71. The article continues: 'In particular, the draft CLERP 9 provisions do not differentiate with regard to: 'cooling off periods' (applicable to all companies other than small proprietary companies); auditor rotation (applicable to all listed companies regardless of size); and expansion of auditor duties (section 311 - applies to all audits). Auditors in regional and rural areas in particular, who act for incorporated entities of significance to their local communities (such as clubs and charities), have indicated that due to the difficulties that will be imposed on them by the current draft bill, they will seriously consider withdrawing from auditing.'

97 'CLERP 9 - Where We Stand', above n 86.

${ }^{98}$ John Shanahan, partner at specialist financial reporting firm, Robertson Shanahan cited in 'Impact of CLERP 9 independence' (2004) 74 (3) Australian CPA 20.

${ }^{99}$ Ibid. To help deal with difficulties flowing from the new 'cooling off' requirements and in an effort to make it easier for companies searching for directors with specific
} 
Most fundamentally, there is much force in the argument that excessive legislation is apt to result in compliance that is merely technical, rather than ethical:

The old concept of form over substance still reigns supreme. As in the past, the authors of future audit reports will still be trying to ensure that the look of those reports complies, or appears to comply, with what the legislation demands. Our legislators ... conveniently ignored the fact that where form can be impressive, it is meaningless if there is no substance. ${ }^{100}$

The crucial area of debate over the CLERP 9 discussion paper related, perhaps predictably, to the issue of whether reform should tend towards 'black-letter law', in which all requisite measures are given the force of law, or 'fuzzy regulation', in which state agencies and the professional bodies are left to ensure compliance with overarching standards. Given its advocacy of 'spot fines', ${ }^{101}$ the force-of-law argument naturally found favour with ASIC. In its response to the CLERP 9 discussion paper, ASIC pointed to deficiencies in the Companies Auditors \& Liquidators Disciplinary Board's operations and penalties structure, opining that the prospect of auditor deregistration was an inadequate compliance incentive. ${ }^{102}$ As has already been noted, however, ASIC was virtually alone in its push for force-of-law reform.

Placing auditing standards under the supervision of the FRC and treating them as delegated legislation with the force of law has a simplistic appeal: this is how the accounting standards are administered. Against this, however, it is argued that cementing standards in legislation 'runs the risk of derailing the momentum towards global harmonisation of auditing standards' ${ }^{103}$ : 'fines will provide little extra in improving performance and will ... undermine much of the good that has been achieved in recent years in global standards setting'. ${ }^{104}$

skill-sets, CPA Australia has created a database of accountants suited to serve on company boards.

100 'CLERP 9 audit reforms add too much complexity', The Australian Financial Review, (Sydney), 20 August 2004, 54.

${ }^{101}$ Although dubbed 'spot fines' by many commentators, this appellation is somewhat misleading: before issuing an infringement notice, ASIC must give notice of its concerns and offer the company concerned an opportunity to give evidence and to make submissions at a private hearing: s1317DAD.

102 'Off the rails' (2003) 74(3) CA Charter 21.

${ }^{103}$ Ibid.

${ }^{104}$ Ibid. 
The more vociferous proponents of fuzzy regulation argue that there was little need for reform at all, positing that 'the reforms introduced in Australia in response to corporate malfeasance in the 1980s appear to have held up under pressure $^{, 105}$ and that black-letter law is 'often only a roadmap for the unscrupulous, as was demonstrated in the Enron off-balance-sheet transactions' ${ }^{106}$ Fuzzy regulation, in contrast, 'tends to encourage companies and people to lift their gaze from regulatory minimums to the principles involved': 107

It is arguably vital that Australia maintains a principled-based approach to regulation and self-regulation. As noted by Bartholomeusz (2002), in making technical compliance with the law less of an issue than compliance with its spirit, the Australian system has offered scope for good governance and practice to evolve and respond to the corporate environment and community expectations. $^{108}$

Other commentators have expressed similar views:

Of particular concern is the way in which the draughtsmen responsible for putting together CLERP 9 have given auditing standards the force of law. If one combines this and the breadth of auditing standards with the oversight role of the FRC and the enforcement role and responsibilities of ASIC, we could end up with an environment that will be nearly as prescriptive and detailed as that now in place in the US ...It is unlikely that it up would add sufficient benefit to outweigh the significant costs of compliance that it would involve. ${ }^{109}$

In a detailed treatment of recent corporate collapses in Australia and the United States, Leung and Cooper draw on a body of American sociological and social-psychological research in arguing that, although lack of effective corporate governance is generally implicated, 'the relationship between materialism and corporate collapses has been largely overlooked by the numerous corporate governance recommendations, which merely scratch the

\footnotetext{
105 Philomena Leung and Barry Cooper, above n39.

${ }^{106}$ Ibid.

${ }^{107}$ Ibid.

108 Ibid.

109 Stephen Harrison, 'All eyes on auditors', CA Charter 74(11) 4. However, it was apparently not the intention of the Australian government to enact a prescriptive, black-letter law regime. Senator Campbell, one of the bill's principal architects, opined that the scheme of the legislation 'promotes corporate governance best practice as opposed to Washington or Canberra saying 'you do not need to think about it - we have done the thinking for you': 'Campbell's law', above n 56.
} 
surface of the problems'. ${ }^{110}$ At the end of the day, it is simply not possible to legislate against materiality and greed:

[W]hile the mountain of black-letter law keeps increasing, as regulations become more intrusive, as prospectuses become crammed with more and more information (with the meeting of mounting official requirements creating the false impression of added security), the corporate collapses keep on getting bigger and directorial fraud gets worse, demonstrating that you cannot legislate for integrity. ${ }^{111}$

\section{Conclusion: A Need to Resurrect the 'True and Fair VieW'}

HIH showed just how easy it was to fool the regulator and the market for a time. Ray Williams craved the market's favour and went to extraordinary lengths to get good coverage from stockbrokers' analysts. Those whose views he disagreed with, he refused to talk to. Eventually the fiddles and tweaking mounted to the point where they broke the company. HIH was juggling so many balls in the air - overstating reserves, heavy use of financial reinsurance, intangibles accounting for $85 \%$ of net assets, and growing losses in the UK and US, at a time the Australian dollar was falling. These factors built so dramatically over 1999 and 2000, that all the massaging HIH could muster could not cover the impending disaster. ${ }^{112}$

Almost without exception, each of the recent high-profile corporate collapses, both here in Australia and the United States, entailed gross deception of the investing public through highly shonky, technical accounting. ${ }^{113}$ Yet compliance with accepted accounting standards is merely one, indeed a subordinate, aspect of the auditor's certification: ultimately, financial reports must present a 'true and fair view'. Unfortunately, as Professors of

\footnotetext{
${ }^{110}$ Philomena Leung. and Barry Cooper, 'The Mad Hatter's Corporate Tea Party', above n 39.

111 'Rigid rules merely make more work', The Australian Financial Review, (Sydney), 12 July 2004, 63.

112 'Why did HIH collapse?' (2003) 74(3) CA Charter, 24.

${ }^{113}$ Damningly, Leung and Cooper perceive the apathy of the auditors involved in these collapses as akin to 'Alice in Wonderland at the Mad Hatter's party': 'They were caught up in the frenzy and wanted to join the party. Their independence collapsed under the threat of being left behind in the new economy revolution. Their belief in the revolution was so pervasive, as well as the belief that the old rules no longer applied, that the gatekeepers became servants to the new players rather than independent guardians. The traditional brakes on the system no longer worked.', above $\mathrm{n} 39$.
} 
Accounting Graeme Dean and Frank Clarke argue, the import of the 'true and fair' criterion in Australia has long been undermined in that 'accountants have been schooled in the belief that the primary criterion for a 'true and fair view' was that the result complied with accounting standards - the so-called technical interpretation. ${ }^{114}$ This may change. Pre-reform, the Corporations Act required directors to explain if the criterion was not met. Under the CLERP 9 Act, directors are now required to explain if they believe that compliance with the accounting standards does not present a true and fair view. Moreover, if additional information is considered necessary to provide a true and fair view, directors must explain why. ${ }^{115}$

Dean and Clarke posit that these changes 'put far more focus on the true and fair criterion'. ${ }^{116}$ If so, then the legislature was extremely coy in its amendments - particularly when compared with its expansive pronouncements on auditor independence. Given that the very purpose of publishing financial reports is to edify the investing public - and given the demonstrated propensity of corporate malfeasors to exploit the accounting profession's arcane vernacular and methodologies - this is a great shame. Much more could have been done. Most fundamentally, guidance could have been provided to directors, auditors and regulators as to what, actually, constitutes a 'true and fair view':

Whilst we like to argue that our approach to financial reporting is conceptual, whereas the US approach is menu or rule driven ... the truth is that in practice our approach is also rule driven and we do not often avail ourselves of the conceptual approach which is embodied in the true and fair view that our system allows. As more and more rules have been developed,

\footnotetext{
${ }^{114}$ Graeme Dean and Frank Clarke, 'True, fair and harder to avoid', Business Review Weekly, 5 August 2004. ASIC has been severely criticised for perpetuating this interpretation: 'In Australia, the Corporations Act has long contemplated enforcement action by ASIC any time there is a failure to take reasonable steps to comply with the 'true and fair view' requirement. But the reality is that ASIC has never sought to enforce this requirement independently of compliance with accounting standards... ASIC accepts that 'there is a valuable oversight role to be played by auditors to ensure that the overall picture is true and fair'. The reality though is that, in practice, ASIC's attitude has been one of the major obstacles that has brought about a state of affairs in which auditors do not, in fact, perform this 'valuable oversight role' Mark Leibler,. 'True and fair - An imaginary view' (2003)13(3) Australian Accounting Review 61.

${ }^{115}$ Corporations Act 2001 (Cth) s298.

${ }^{116}$ Dean and Clarke, above n 114.
} 
less and less attention has been given to the true and fair requirement, to the extent that young auditors would no longer really know how to apply it. ${ }^{117}$

Re-establishing the 'true and fair view' as the ultimate reporting criterion would go a long way toward deflecting criticisms that the CLERP 9 amendments impose a black-letter regime offering only a 'roadmap for the unscrupulous'. Yet even its universal and unwavering application could never redress unscrupulous conduct per se:

As a result of the searching inquiries of the Royal Commission into the $\mathrm{HIH}$ collapse, we now know some of the devices HIH management used to trick its auditor, the regulator and its own directors. The executives involved knew what they were doing was wrong, yet they did it. No system of regulation can rule against behaviour like this. ${ }^{118}$

Perhaps with apprehensions otherwise, the Australian Government has unfortunately imposed a regime that is not only costly to implement but which tends towards technical rather than ethical compliance and which, in the process, misses two crucial targets: a standard of auditor independence that is intolerant of even the perception of impartiality and a financial disclosure criterion that punishes deception of the investing public.

117 David Boymal, National Director, Accounting \& Auditing Standards, Ernst \& Young, 63rd CPA Annual Research Lecture, 26 August 2002 (quoted in Mark Leibler, above n 114).

118 'Why did HIH collapse?', above n 112. 